\title{
ANALISIS IMPLEMENTASI PENCEGAHAN DAN PENGENDALIAN INFEKSI DI RSUD DATU BERU TAKENGON
}

\author{
Azakani Rahmadan ${ }^{1}$, Juliandi Harahap ${ }^{2}$, Mappeaty Nyorong ${ }^{3}$ \\ 1,2,3 Institut Kesehatan Helvetia, Medan \\ Email: azakaniramadan@gmail.com
}

\begin{abstract}
Abstrak
Kesehatan merupakan kebutuhan dasar setiap manusia, seseorang tidak bisa memenuhi seluruh kebutuhan hidupnya jika berada dalam kondisi tidak sehat, sehingga kesehatan merupakan modal setiap individu untuk meneruskan kehidupannya secara layak. Salah satu misi yang telah ditetapkan dalam Rencana Strategis Departemen Kesehatan 2019 adalah Standar Pelayanan Minimal bidang Kesehatan yang selanjutnya disebut SPM Kesehatan merupakan ketentuan mengenai Jenis dan Mutu Pelayanan Dasar yang merupakan Urusan Pemerintahan Wajib yang berhak diperoleh setiap Warga Negara secara minimal. Kepala ruangan harus menguasai proses manajemen yang dinamis dan senantiasa berubah sesuai dengan perkembangan jaman. Manajemen merupakan proses mengorganisir sumber sumber untuk mencapai tujuan dimana arah tujuan yang akan di capai ditetapkan berdasarkan visi, misi, filosofi organisasi. Manajemen keperawatan yang dipimpin adalah proses bekerja melalui anggota staf keperawatan atau memberikan asuhan, pengobatan dan bantuan terhadap para pasien. Tujuan penelitian ini adalah mengeksplorasi secara mendalam bagaimana kemampuan manajemen kepala ruang rawat inap di RSUD Datu Beru Takengon Aceh Tengah tahun 2021. Jenis penelitiannya yaitu Kualitatif deskriftif Penelitian ini dilakukan di RSUD Datu Beru Takengon, informan berjumlah 10 orang terdiri dari Direktur RSUD 1 orang , kepala bidang keperawatan 1 orang, kepala ruangan sebanyak 3 orang dan Perawat Pelaksana sebanyak 5 orang yang ada di RSUD Datu Beru Takengon. Hasil penelitian menunjukkan bahwa fungsi perencanaan sudah terencana cukup baik, fungsi pengorganisasian belum cukup baik pada pembagian kerja dan tidak terstruktur, fungsi pengarahan sudah dilaksanakan dengan cukup baik namun tidak ada sytem reward, fungsi pengendalian masih kurang baik pada penilayan kinerja staf, tidak ada indicator kualitas dokumen asuhan keperawatan dan tidak ada menilai kepuaan pasien dan kepuasan staf, pada fungsi pengawasan belum cukup baik pada pendokumentasian keperawatan. Saran peneliti agar tenaga kesehatan melaksanakan pelaksanan manajemen kepala ruangan dengan baik untuk meningkatkan mutu pelayanan kesehatan.
\end{abstract}

Kata Kunci : Kemampuan Kepala Ruang, Meningkatkan Mutu Pelayanan

\begin{abstract}
Abstrak
Health is a basic need of every human being, a person cannot fulfill all the needs of his life if he is in an unhealthy condition. So that health is the capital of every individual to continue his life properly. One of the missions set out in the 2019 Ministry of Health's Strategic Plan is the Minimum Service Standard in the Health sector, hereinafter referred to as the Health MSS, which is a provision regarding the Type and Quality of Basic Services which are Mandatory Government Affairs that every citizen has the right to obtain at a minimum. The head of the room must master the management process that is dynamic and constantly changing according to the times. Management is the process of organizing resources to achieve goals where the direction of the goals to be achieved is determined based on the vision, mission, and philosophy of the organization. Nursing-led management is the process of working through members of the nursing staff or providing care, treatment and assistance to patients. The purpose of this study is to explore in depth
\end{abstract}


how the management ability of the head of the inpatient room at Datu Beru Takengon Hospital, Central Aceh in 2021. The type of research is descriptive qualitative. This research was conducted at Datu Beru Takengon Hospital, there were 10 informants consisting of the Director of the RSUD 1 person, the head of the nursing field 1 person, the head of the room as many as 3 people and the Implementing Nurse as many as 5 people in the Datu Beru Takengon Hospital. The results showed that planning management was well planned, organizational management about the organizational structure was not in accordance with the task, directive management had been carried out properly, management control still lacked nursing care and work performance did not exist and nursing documentation was not complete and there was no assessment. nurse satisfaction and patient satisfaction, management supervision. Suggestions for patients and health workers to carry out good management to improve the quality of health services.

\section{Keywords: Head of Room Ability, Improving Service Quality}

\section{Pendahuluan}

Kesehatan merupakan kebutuhan dasar setiap manusia, seseorang tidak bisa memenuhi seluruh kebutuhan hidupnya jika berada dalam kondisi tidak sehat. Sehingga kesehatan merupakan modal setiap individu untuk meneruskan kehidupannya secara layak. Salah satu misi yang telah ditetapkan dalam Rencana Strategis Departemen Kesehatan 2019 adalah Standar Pelayanan Minimal bidang Kesehatan yang selanjutnya disebut SPM Kesehatan merupakan ketentuan mengenai Jenis dan Mutu Pelayanan Dasar yang merupakan Urusan Pemerintahan Wajib yang berhak diperoleh setiap Warga Negara secara minimal (Syam, 2017)

Pelayanan kesehatan masa kini sudah merupakan industri jasa kesehatan. dimana setiap rumah sakit bertanggung gugat terhadap penerimaan jasa pelayanan kesehatan, keberadaan dan mutu pelayanan kesehatan yang diberikan ditentukan oleh nilai-nilai dan harapan dari penerima jasa pelayanan, disamping itu, penekanan pelayanan kepada mutu yang tinggi harus dapat dicapai dengan biaya yang dapat dipertanggung jawabkan. Dengan demikian, semua pemberian pelayanan ditekankan untuk mënurunkan biaya pelayanan namun mutu pelayanan (quality assurance) dan kepuasan kepada pasien sebagai konsumen masih tetap menjadi tolak ukur utama keberhasilan pelayanan kesehatan yang diberikan (Surahmat, dkk, 2019)

Manajer atau Kepala Ruang operasional merupakan pimpinan yang secara langsung mengelola seluruh sumber daya di unit perawatan untuk menghasilkan pelayanan yang bermutu. Kepala Ruang merupakan jabatan yang cukup penting dan strategis, karena secara manajerial kemampuan kepala ruang ikut menentukan keberhasilan pelayanan keperawatan (Galleryzki, dkk, 2021)

Keperawatan telah banyak berfokus pada manajemen rincian sehari-hari dan kurang memperhatikan kepemimpinan, lingkugan asuhan keperawatan membutuhkan perawat yang mengatur tujuan klinis klien juga melakukan peran kepemimpinan dalam mencapai mutu pelayanan yang optimal hal ini yang ditangkap peneliti terhadap manajemen keperawatan dari kepala ruang rawat inap RSUD Datu Beru Takengon. 
Di RSUD Datu Beru mesti setiap tahun kualitas kepala ruangan meningkat namun masih ada pasien yang mengeluhkan staf bekerja di ruangan sangat jarang mengunjungi pasien untuk menjelaskan keadaan pasien, tindakan yang di lakukan staf rawat inap tampa melakukan penjelasan terhadap obat yang di berikan, staf hanya melakukan intruksi dokter tampa melakukan proses keperawatan, kemudian kurangnya seorang pemimpin ruangan untuk berkomunikasi terhadap staf, kepala ruangan tidak melakukan perencanaan terhadap pengendalian mutu pelayanan keperawatan, kepala ruangan belum cukup baik dalam hal pengawasan di karnakan pulang lebih awal, tidak melakukan pengawasan terhadap proses keperawatan, kepala ruangan tidak melakukan pengelompokan untuk membahas tentang asuhan keperawatan untuk meningkatkan mutu pelayanan, tidak ada rewed terhadap staf yang berprilaku positif dan bahkan ada staf yang berkeinginan untuk mengganti kepala ruangannya.

RSUD Datu Beru Takengon adalah Rumah Sakit yang dimiliki oleh pemerintah Kabupaten Aceh Tengah, Kepemilikan / Badan Hukum 445.1/BP2T/1427/2013, Type / Klas B Akriditasi Paripurna di pimpin oleh dr. Hardi Yanis,Sp.PD dengan jumlah kariawan 801 orang 32 dokter Umum 36 dokter Spesialis, 576 Paramedis 172 Non Paramedis.

Berdasarkan survey yang peneliti lakukan RSUD Datu Beru Takengon Kabupaten Aceh Tengah kepada beberapa tenaga Perawat dan Dokter yang telah peneliti wawancarai. Dari segi wawancara tersebut peneliti menemukan ada beberapa hal yang mempengaruhi kualitas kinerja kepala ruangan di RSUD Datu Beru Takengon mengenai Tingkat Kemampuan Manajemen Kepemimpinan seperti perencanaan, pengarahan, pengorganisasian, pengontrolan dari benda dan manusia untuk mencapai tujuan yang telah ditentukan sebelumnya dan evaluasi. Selanjutnya Swanburg mendefinisikan manajemen sebagai ilmu atau seni tentang bagaimana menggunakan sumber daya secara efisien, efektif dan rasional untuk mencapai tujuan organisasi yang telah ditetapkan sebelumnya. Sedangkan Manajemen terhadap Asuhan Keperawatan yaitu panduan untuk memberikan asuhan keperawatan professional, baik untuk individu, kelompok, keluarga dan komunitas dalam hal mengelola pasien menggunakan proses keperawatan yaitu pengkajian, diagnosa, perencanaan, implementasi dan evaluasi (Ilfa, dkk, 2020).

Dari faktor yang disebut diatas masih kurangnya tingkat kemampuan kepala ruangan rawat inap untuk menerapkan manajemen kepemimpinan dan manajmen asuhan keperawatan sehingga menyebabkan kurangnya mutu pelayanan di RSUD Datu Beru Takengon.

Menurut Thoha 2013 dalam buku kepemimpinan mengemukakan bahwa suatu organisasi akan berhasil atau bahkan gagal, sebagian besar ditentukan oleh kepemimpinan yang ada. Kepemimpinan adalah suatu kekuatan yang menggerakan perjuangan atau kegiatan menuju sukses. Kepemimpinan juga berarti proses mempengaruhi aktivitas kelompok dalam rangka perurumusan dan pencapaian tujuan.

Berdasarkan uraian latar belakang diatas, maka tujuan penelitian ini adalah untuk menganalisis tingkat kemampuan kepala ruang rawat inap dalam meningkatkan mutu pelayanan di rsud datu beru takengon di antaranya yang berhubungan dengan Manajemen kepemimpinan dan Manajemen Keperawatan. 


\section{Metode Penelitian}

Desain penelitian ini merupakan studi analisis deskripsi dengan pendekatan kualitatif, untuk menemukan makna dari hal-hal mendasar dan esensial dari realitas serta pengalaman yang dialami oleh objek penelitian sehingga didapatkan informasi secara mendalam mengenai tingkat kemampuan kepala ruang rawat inap dalam meningkatkan mutu pelayanan di RSUD Datu Beru Takengon.

\section{Hasil dan Pembahasan}

Informan utama yang bersedia dalam penelitian dilaksanakan di RSUD Datu Beru Takengon Kabupaten Aceh Tengah, Aceh yaitu:

Tabel 4.1 Karakteristik Informan Utama

\begin{tabular}{|c|c|c|}
\hline No & Informan & Jumlah \\
\hline 1. & Kepala Ruangan & 3 orang \\
\hline & Jumlah Informan & 3 orang \\
\hline
\end{tabular}

\section{Informan Pendukung}

Pada informan pendukung ini yang ditentukan dengan berdasarkan pertimbangan dapat memiliki pengetahuan dan yang berhubungan dengan informan utama .

Tabel 4.2 Karakteristik Informan Pendukung

\begin{tabular}{|c|c|c|}
\hline No & Informan & Jumlah \\
\hline 1. & Perawat Pelaksana & 1 orang \\
\hline 2. & Perawat Pelaksana & 1 orang \\
\hline 3. & Perawat Pelaksana & 1 orang \\
\hline 4. & Perawat Pelaksana & 1 orang \\
\hline 5. & Perawat Pelaksana & 1 orang \\
\hline & Jumlah Informan & 5 orang \\
\hline
\end{tabular}

\section{Proses Penelitian}

Pengumpulan data dari informan menggunakan metode indepth interview (wawancara mendalam). Pemilihan subjek penelitian dilakukan dengan menemukan informan terlebih dahulu, Kepala Ruangan.

Sedangkan informan pendukung Perawat Pelaksana Ruang Rawat Inap yang ditemui langsung pada saat dilakukan wawancara.

Pertama sekali yang dilakukan peneliti adalah dengan mengajukan surat yang telah diterima dari Institut pendidikan, peneliti mengantar surat tersebut ke RSUD Datu 
Beru Takengon tempat melakukan penelitian. Setelah surat ditanggapi oleh pihak manajemen RSUD Datu Beru Takengon, peneliti menyusun gambaran informan yang sesuai dengan penelitian. Kemudian peneliti menentukan siapa-siapa saja yang menjadi informan pendukung dalam penelitian, setelah itu peneliti mendatangi informan untuk menanyakan apakah informan tersebut bersedia dilakukan wawancara serta meminta waktu yang tepat untuk melakukan wawancara tersebut. Setelah meminta kesiapan waktu untuk dilakukan wawancara sesuai dengan penelitian. Pada minggu pertama peneliti mendatangi Informan yaitu sebagai informan Utama. Pada hari berikutnya peneliti menemui informan pendukung, dan dilakukan wawancara dan meminta waktunya sebentar.

Setelah melakukan permohonan kepada semua informan, peneliti menemui informan dimana peneliti melakukan wawancara langsung yang di bantu oleh 1 (satu) orang teman peneliti untuk mengambil dokumentasi, dan wawancara berlangsung dengan baik dan informasi diperoleh oleh peneliti dengan jelas.

Hasil wawancara dengaan Informan Utama dan Informan Pendukung menganalisis kemampuan kepala ruangan rawat inap berdasarkan manajemen perencanaan di RSU Datu Beru Takengon

Berdasarkan hasil wawancara responden, Peneliti menyimpulkan bahwa informan utama dan informan kemampuan kepala ruangan rawat inap berdasarkan manajemen perencanaan. Didapatkan hasil wawncara mendalam bahwa semua informan mengatakan sudah memiliki manajemen perencanaan bulanan dan juga mingguan dalam meningkatkan kualitas mutu pelayanan kesehatan. Namun meskipun demikian perencanaan tahunan tidak ada dilakukan.

Menurut penelitian juga menunjukkan bahwa perencanaan kepala ruangan sudah terencana dengan baik tetapi kinerja perawatnya masih kurang baik. Dengan menentukan perencanaan yang baik, maka secara tidak langsung tahap pelaksanaan akan mendapat hasil yang lebih baik pula sebaliknya apabila penentuan perencanaan sudah cukup baik secara tidak langsung tahap pelaksanaan akan mendapat hasil yang cukup pula.

Hasil wawancara dengaan Informan Utama dan Informan Pendukung menganalisis kemampuan kepala ruangan rawat inap berdasarkan manajemen pengorganisasian di RSU Datu Beru Takengon

Berdasarkan hasil wawancara responden, Peneliti menyimpulkan bahwa informan utama dan informan kemampuan kepala ruangan rawat inap berdasarkan manajemen pengorganisasian. Berdasarkan hasil wawancara didapatkan bahwa pengorganisasian dalam bidang tidak dilakukan dikarenakan semua perawat memiliki peran yang sama baik bidan dan perawat. namun Masalah koordinasi antar ruangan lain menunjukkan bahwa kepala ruangan selalu berkoordinasi dengan ruangan lain untuk membantu apa yang dibutuhkan dari ruangan lain.

Menurut peneliti dengan manajemen pengorganisasia perawat tidak mendapatkan penugasan/ wewenang secara baik. Masalah pengelompokan kegiatan tidak dibuat sama dengan kegiatan pada rumah sakit yang lainnya, dimana kegiatan dilakukan berdasarkan tindakan atau kasus dari keluhan pasien. Begitu juga dengan membuat shift kerja, kepala ruangan selalu membuat berdasarkan jumlah jam kerja dan dibagi dengan jumlah perawat. Masalah struktur organisasi masi belum terarah di karnakan tidak adanya penetapan struktur organisasi sesuai dengan kemampuan perawat.

Hasil Wawancara dengaan Informan Utama dan Informan Pendukung menganalisis kemampuan kepala ruangan rawat inap berdasarkan manajemen pengarahan di RSU Datu Beru Takengon 
Berdasarkan hasil wawancara responden, Peneliti menyimpulkan bahwa informan utama dan informan kemampuan kepala ruangan rawat inap berdasarkan manajemen pengarahan didapatkan bahwa informan utama mengatakan sudah memberikan pengarahan kepada perawat dalam pelaksanaan kegiatan tindakan medis, didukung dari informan pendukung mengatakan bahwa ketika ada masalah tindakan atau masalah yang tidak bisa tangani oleh perawat maka kepala ruangan akan membantu melaksanakannya dan memberikan pengarahan. Tetapi tidak untuk memberikan reward terhadap perawat pelaksananya.

Menurut peneliti dengan Asumsi peneliti bimbingan dan pengarahan yang dilakukan oleh kepala ruangan merupakan motivasi dan dapat menambah pengetahuan bagi perawat pelaksana apabila selalu dilakukan dengan rutin, maka perawat pelaksana akan memiliki tanggung jawab terhadap kelengkapan pengisian dokumentasi keperawatan dan dilaksanakan dengan konsisten. Tetapi apa bila tidak di lakukan system reward terhadap setaf akan mengurangi semangat staf untuk melakukan hal yang bersifat mengembangkan diri.

\section{Hasil Wawancara dengaan Informan Utama dan Informan Pendukung menganalisis kemampuan kepala ruangan rawat inap berdasarkan manajemen pengendalian di RSU Datu Beru Takengon}

Berdasarkan hasil wawancara diatas Peneliti menyimpulkan bahwa informan utama dan informan kemampuan kepala ruangan rawat inap berdasarkan manajemen pengendalian. Berdasarkan hasil matriks dapat disimpulkan bahwa kepala ruangan tetap melakukan audit dokumen dari tiap-tiap perawat untuk melihat peningkatan kemampuan perawat dalam melakukan asuhan keperawatan, tetapi kepala ruangan tidak pernah melakukan survei kepuasan terhadap pasien yang pulang. Kepala ruangan juga tidak pernah melakukan survei kepuasan kepada pasien dan para perawat sesuai dengan format yang ditetapkan. Selanjutnya kepala ruangan tidak pernah membuat atau melakukan survei kepuasan terhadap pasien dan perawat.

Masalah penilaian kegiatan pendokumentasian belum dilakukan dengan baik. Kepala ruangan juga belum menilai kegiatan dari masing-masing perawat untuk menilai prestasi dari perawat dalam melakukan asuhan keperawatan dengan baik, begitu juga dengan pendokumentasian, dimana kepala ruangan hanya mengajak perawat untuk saling membantu dalam mencapai asuhan keperawatan yang maksimal.

\section{Hasil Wawancara dengaan Informan Utama dan Informan Pendukung menganalisis kemampuan kepala ruangan rawat inap berdasarkan manajemen pengawasan di RSU Datu Beru Takengon}

Berdasarkan hasil wawancara terhadap responden, Peneliti menyimpulkan bahwa informan utama dan informan kemampuan kepala ruangan rawat inap berdasarkan manajemen pengawasan. Berdasarkan hasil matriks dapat disimpulkan bahwa pengawasan staf keperawatan sudah dilakukan, keperawatan mampu melakukan penilaian kemampuan perawat dalam melakukan asuhan keperawatan tetapi tidak di buat di dokumentasi asuhan keperawatan, walaupun pengawasan dilakukan belum dengan maksimal. Kepala ruangan selalu melakukan pengecekan keruangan dan melihat kebersihan ruangan dan status pasien untuk memaksimalkan kinerja perawat dalam asuhan keperawatan dan kepala ruangan juga memberikan penilian terhadap peningkatan pengetahuan dan kemampuan dari tiap-tiap perawat. Selanjutnya menurut komite keperawatan dan kepala ruangan tidak pernah melakukan kerja sama dengan pihak supervisi secara jelas. Kepala ruangan hanya mengandalkan usaha sendiri untuk melakukan penilaian kemampuan perawat untuk meningkatkan asuhan keperawatan dengan baik. 
Lembar observasi RSUD Datu Beru Takengon tingkat kemampuan manajemen
kepala ruang rawat inap di RSUD Datu Beru Takengon Aceh Tengah tahun 2021.

Berdasarkan hasil Lembar Observasi diatas Peneliti menyimpulkan bahwa informan utama dan informan tingkat kemampuan manajemen kepala ruang rawat inap di RSUD Datu Beru Takengon Aceh Tengah tahun 2021 didapatkan sebagai berikut:

\begin{tabular}{|c|l|c|c|c|c|}
\hline No. & \multicolumn{1}{|c|}{ Nama Dokumen } & Ada & Tidak & Sesuai & Tidak Sesuai \\
\hline 1 & SAK dan SOP & 10 & & & \\
\hline 2 & Kesesuaiyan ASKEP di RM & 5 & & & 5 \\
\hline 3 & $\begin{array}{l}\text { Program perencanaan } \\
\text { tahunan, bulanan, harian }\end{array}$ & 10 & & & \\
\hline & Dst & 10 & & & \\
\hline
\end{tabular}

Hasill Lembar Observasi diatas Peneliti menyimpulkan bahwa informan utama dan informan tingkat kemampuan manajemen kepala ruang rawat inap di RSUD Datu Beru Takengon Aceh Tengah tahun 2021 . Setiap perawat dalam melaksanakan tugasnya harus menggunakan proses keperawatan untuk mencapai tujuan asuhan keperawatan pasien. Proses Keperawatan merupakan proses pemecahan masalah yg menekankan pada pengambilan keputusan tentang keterlibatan perawat sesuai yang dibutuhkan pasien. Namun hal Dokumen SAK dan SOP sudah ada dalam pelaksanaan di RSUD Datu Beru Takengon Aceh Tengah, meskipun Askep Sudah ada, namun kesesuaiannya masi kurang, hal ini di dukung dengan adanya hasil wawancara bahwa askep ada namun tidak secara mendalam. Sedangkan perencanaan sudah ada dilakukan setiap bulan dan minggu untuk meningkatkan mutu pelayanan kesehatan di di RSUD Datu Beru Takengon Aceh Tengah

\section{Kemampuan Kepala Ruangan Rawat Inap Berdasarkan Manajemen Perencanaan Di RSU Datu Beru Takengon.}

Berdasarkan hasil wawancara diatas Peneliti menyimpulkan bahwa informan utama dan informan kemampuan kepala ruangan rawat inap berdasarkan manajemen perencanaan. Didapatkan hasil wawncara mendalam bahwa semua informan mengatakan sudah memiliki manajemen perencanaan bulanan, mingguan dan harian dalam meningkatkan kualitas mutu pelayanan kesehatan. Namun meskipun demikian perencanaan tahunan tidak ada dilakukan .

Dengan melakukan perencanaan tahunan, bulanan, mingguan dan harian dapat terlaksana maka penetapan visi dan misi tujuan rumah sakit akan terlaksana secara optimal dalam memperbaiki mutu pelayanan keperawatan. Dengan menentukan perencanaan yang baik, maka secara tidak langsung tahap pelaksanaan akan mendapat hasil yang lebih baik pula sebaliknya apabila penentuan perencanaan kurang baik secara tidak langsung tahap pelaksanaan akan mendapat hasil yang kurang pula.

Sejalan dengan penelitian yang dilakukan Dewi dimana ada hubungan yang bermakna antara fungsi manajemen perencanaan kepala ruangan dengan penerapan keselamatan pasien dimana nilai $\mathrm{p}=0,032$. Hal ini dikarenakan penelitian dilakukan ditempat yang berbeda dengan karakteristik responden yang berbeda (Astuti, dkk, 2017)

Asumsi peneliti apabila perencanaan dilakukan dengan baik oleh kepala ruangan dan perencanaan terealisasi dilapangan dengan baik maka dokumentasi keperawatan 
dapat terisi dengan lengkap dan sebaliknya jika perencanaan tidak dilakukan maka dokumentasi keperawatan tidak terisi lengkap, penelitian juga menunjukkan bahwa perencanaan kepala ruangan sudah terencana dengan baik tetapi kinerja perawatnya masih kurang baik hal ini dapat dipengaruhi oleh karakteristik perawat di ruang rawat inap seperti pendidikan, masa kerja serta pengetahuan hal ini dipengaruhi karakteristik perawat yaitu pengetahuan dan pendidikan perawat di ruangan. Dengan menentukan perencanaan yang baik. Maka secara tidak langsung tahap pelaksanaan akan mendapat hasil yang lebih baik pula sebaliknya apabila penentuan perencanaan sudah cukup baik secara tidak langsung tahap pelaksanaan akan mendapat hasil yang cukup pula.

\section{Kemampuan Kepala Ruangan Rawat Inap Berdasarkan Manajemen Pengorganisasian Di RSU Datu Beru Takengon.}

Berdasarkan hasil wawancara diatas Peneliti menyimpulkan bahwa informan utama dan informan pendukung kemampuan kepala ruangan rawat inap berdasarkan manajemen pengorganisasian. Berdasarkan hasil wawancara didapatkan bahwa pengorganisasian dalam bidang keperawatan tidak dilakukan dikarenakan semua perawat memiliki peran yang sama baik bidan dan perawat yang hanya melakukan metode fungsional dan untuk struktur organisasi belum terarah, namun masalah koordinasi antar ruangan lain menunjukkan bahwa kepala ruangan selalu berkoordinasi dengan ruangan lain untuk membantu apa yang dibutuhkan dari ruangan lain, begitu juga dengan kerja sama, dimana kepala ruangan mengajak perawat untuk saling membantu dalam mencapai asuhan keperawatan yang maksimal

Sejalan dengan penelitian yang dilakukan oleh Parmin dimana ada hubungan yang signifikan antara fungsi manajemen kepala ruangan pada fungsi Pengorganisasian dengan motivasi kerja perawat pelaksana dengan nilai $\mathrm{p}=0,022$. Menurut Siswanto Fungsi pengorganisasian bertujuan untuk 1) menjamin kontinuitas perencanaan. 2) membudayakan prosedur standar. 3) menghindari kemangkiran yang tak berarti. 4). membina disiplin kerja. Fungsi pengorganisasian adalah menentukan tugas-tugas yang harus dikerjakan (Tampubolon, 2019)

Pendelegasian tugas merupakan bagian yang tidak terpisahkan dari pengelolaan ruangan Pendelegasian digolongkan menjadi 2 jenis yaitu terencana dan insidentil. Pendelegasian terencana adalah pendelegasian yang memang otomatis terjadi sebagai konsekuensi sistem penugasan yang diterapkan di ruang rawat inap, bentuknya dapat pendelegasian tugas kepala ruang kepada ketua tim, kepada penanggung jawab shift. Pendelegasian insidentil terjadi bila salah satu personil ruang rawat inap berhalangan hadir, maka pendelegasian tugas harus dilakukan (Maleong, 2018). Komunikasi yang efektif dapat dilakukan baik lisan maupun tertulis. Komunikasi lisan diselenggarakan melalui proses : operan, konferens, konsultasi, dan informal antar staf. Komunikasi tertulis diselenggarakan melalui media yaitu papan tulis, buku laporan ruangan, atau pesan-pesan khusus tertulis.

Peran kepala ruangan sangat penting dalam metode tim untuk itu kepala ruangan di harapkan menetapkan setandar kinerja yang diharapkan, membantu menetapkan sasaran dari ruangan, memberikan kesempatan kepada ketua tim untuk pengembangan kepemimpinan dengan demikian secara otomatis pelayanan yang di berikan kepada pasien akan lebih tepat dan mencukupi sehingga dapat meningkatkan kualitas mutu pelayanan di rumah sakit. 


\section{Kemampuan Kepala Ruangan Rawat Inap Berdasarkan Manajemen Pengarahan Di RSU Datu Beru Takengon.}

Berdasarkan hasil penelitian pengaruh bimbingan dan pengarahan kepala ruangan terhadap kinerja perawat sudah dilakukan dan di arahkan agar dapat melakukan tindakan dengan baik dan benar, kepala ruangan membantu mengidentifikasi masalah, memberi motivasi dan melakukan komunikasi secara efektif tetapi masih belum melakukan system reward hal ini perlu dilakukan untuk meningkatkan keinginan staf untuk lebih kompeten.

Tujuan dari dilakukan pengarahan adalah mengorientasi staf dalam pelaksanaan asuhan keperawatan, memberikan arahan dalam pelaksanaan tugasnya agar menyadari dan mengerti terhadap peran dan fungsi sebagai staf dan pelaksana asuhan keperawatan, memberikan layanan kemampuan staf dan pelaksana keperawatan dalam memberikan asuhan keperawatan, memberikan layanan kemampuan staf dan pelaksanaan dokumentasi keperawatan dalam memberikan asuhan serta mengusahakan seoptimal mungkin kondisi kerja yang nyaman.

Tetapi dilapangan masih terjadi ketidak lengkapan pengisian dokumentasi asuhan keperawatan hal ini disebabkan kepala ruangan tidak melaksanakan bimbingan dan pengarahan kepada perawat pelaksana, hal ini karena kepala ruangan kurang mampu memberi motivasi dan arahan dalam tugas dan tanggung jawabnya sebagai kepala ruangan.

\section{Kemampuan Kepala Ruangan Rawat Inap Berdasarkan Manajemen Pengendalian Di RSU Datu Beru Takengon}

Berdasarkan hasil wawancara diatas Peneliti menyimpulkan bahwa informan utama dan informan kemampuan kepala ruangan rawat inap berdasarkan manajemen pengendalian, berdasarkan hasil matriks dapat disimpulkan bahwa pengendalian staf keperawatan belum dilakukan dengan baik, kepala ruangan tidak menetapkan melakukan pengukuran prestasi yang dimiliki sataf, dan tidak ada penilayan terhadap dokumentasi asuhan keperawatan juga tidak melakukan penilayan kepuasan terhadap pasien dan perawat, kepala ruangan hanya mengandalkan usaha sendiri dan melihat sehari hari kemampuan setafnya yang sudah di anggap mampu untuk melakukan asuhan keperawatan dengan baik.

Berdasarkan penelitian menurut Elis Anggeria dan Maria (2018), mengemukakan bahwa terdapat hubungan supervisi dengan pelaksanaan asuhan keperawatan. Supervisi berperan untuk mengarahkan, membimbing dan mengobservasi (pengawasan) pelaksanaan asuhan keperawatan. Dalam penelitian penelitian menyebutkan bahwa kepala ruang belum optimal dalam melakukan pengendalian terkait evaluasi terhadap pendokumentasian asuhan keperawatan (Salasa, 2021).

Penelitian yang sama juga didapatkan oleh Rahmah (2013) di RSUD Mohammad Saleh didapatkan ada hubungan supervisi dengan dokumentasi asuhan keperawatan. Dan juga menurut penelitian yang di lakukan Ningsih (2010) terdapat hubungan yang sangat signifikan antara pelaksana di ruangan di ruangan rawat inap RSUD dr. Soebandi Jember (Rahmah, 2017) 
Evaluasi juga dapat mengindetifikasi masalah-masalah dan hambatan yang dihadapi oleh perawat pelaksana. Pengawasan dan Evaluasi yang dilakukan kepala ruangan juga dapat menilai target yang dicapai dan penilaian terhadap perawat, jika belum maksimal kepala ruangan kembali mengarahkan perawat supaya konsisten dalam pendokumentasian asuhan keperawatan mulai dari tahap pengkajian, diagnosa, intervensi, implementasi dan evaluasi serta pendokumentasian sesuai dengan ketentuan yang ditetapkan, dimana hal tersebut merupakan tanggung jawab dan tanggung gugat perawat serta mempunyai nilai hukum. Dalam hal ini kepala ruangan belum melakukan pengawasan dan evaluasi terhadap kinerja perawat dalam pendokumentasian asuhan keperawatan karena mendapat tugas tambahan seperti menjadi tim kesehatan pada satuansatuan lain di luar rumah sakit.

Berdasarkan hasil wawancara diatas Peneliti menyimpulkan bahwa informan utama dan informan kemampuan kepala ruangan rawat inap berdasarkan manajemen pengendalian didapatkan bahwa informan utama mengatakan belum melakukan penetapan standar dan pengukuran prestasi kerja kepada perawat dalam pelaksanaan kegiatan tindakan medis, didukung dari informan pendukung mengatakan bahwa tidak ada penilayan terhadap pendokumentasian asuhan keperawatan.

\section{Kemampuan Kepala Ruangan Rawat Inap Berdasarkan Manajemen Pengawasan Di RSU Datu Beru Takengon.}

Hasil penelitian, peneliti menganalisa bahwa belum melaksanakan pengawasan dengan baik. Pelaksanaan pengawasan fungsi manajemen ini didukung dari semua pernyataan partisipan pada wawancara mendalam. Pada saat wawancara dalam manajemen pengawasan adalah pengawasan terhadap kualitas pendokumentasian asuhan keperawatan dan tidak lengkap tersusun sesuai dengan asuhan keperawatan professional yaitu pengkajian, diagnose, intervensi, implementasi dan evaluasi di rumah sakit hanya melakukan asuhan keperawatan fungsional yang berfokus pada tindakan yang di anjurkan saja.

fungsi pengawasan idealnya dilakukan setiap saat di ruangan karena tujuan dari manajemen ruangan adalah memberikan pelayanan keperawatan yang berkualitas kepada pasien selama masa perawatan. Fungsi pengawasan kepala ruang yang baik mempunyai pengaruh terhadap pelaksanaan asuhan keperawatan yang baik pula. Hasil penelitian menunjukkan bahwa kepala ruangan menyisakan waktu untuk mengatur kualitas pelayanan yang baik namun tidak dalam manajemen asuhan keperawatan.

Hal ini juga dibuktikan dari hasil observasi dilapangan masih terjadi ketidak lengkapan pengisian dokumentasi asuhan keperawatan profesional hal ini disebabkan kepala ruangan tidak melaksanakan bimbingan dan pengarahan kepada perawat pelaksana dalam hal asuhan keperawatan yang lengkap dan professional.

\section{Lembar Observasi}

Hasill Lembar Observasi diatas Peneliti menyimpulkan bahwa informan utama dan informan tingkat kemampuan manajemen kepala ruang rawat inap di RSUD Datu Beru Takengon Aceh Tengah tahun 2021 . Setiap perawat dalam melaksanakan tugasnya harus 
menggunakan proses keperawatan untuk mencapai tujuan asuhan keperawatan pasien. Proses Keperawatan merupakan proses pemecahan masalah yg menekankan pada pengambilan keputusan tentang keterlibatan perawat sesuai yang dibutuhkan pasien, namun hal Dokumen SAK dan SOP sudah ada dalam pelaksanaan di RSUD Datu Beru Takengon Aceh Tengah, meskipun asuhan keperawatan sudah ada namun kesesuaiannya masi kurang, hal ini di dukung dengan adanya hasil wawancara bahwa askep ada namun tidak secara mendalam. Sedangkan perencanaan sudah ada dilakukan setiap bulan dan minggu untuk meningkatkan mutu pelayanan kesehatan di di RSUD Datu Beru Takengon Aceh Tengah.

Upaya kesehatan yang dimaksud adalah setiap kegiatan dan/atau serangkaian kegiatan yang dilakukan secara terpadu, terintregasi dan berkesinambungan untuk memelihara dan meningkatkan derajat kesehatan masyarakat dalam bentuk pencegahan penyakit, peningkatan kesehatan, pengobatan penyakit, dan pemulihan kesehatan oleh Pemerintah dan/atau masyarakat.

Moekijat menyatakan bahwa kemauan seseorang untuk melakukan suatu pekerjaan dapat dipengaruhi oleh faktor yang berasal dari luar maupun dari dalam seperti yang disampaikan oleh Herzberg dalam teori motivasinya, bahwa ada dua jenis faktor yang mendorong seseorang untuk berusaha mencapai kepuasan dan menjauhkan diri dari ketidakpuasan. Dua faktor itu disebutnya faktor higiene (faktor ekstrinsik) dan faktor motivator (faktor intrinsik). Faktor higiene memotivasi seseorang untuk keluar dari ketidakpuasan, termasuk di dalamnya adalah kebijakan dan administrasi, supervisi, kondisi kerja, hubungan antar manusia, imbalan, kondisi lingkungan, dan keamanan (faktor ekstrinsik) (Trianengsih, dkk, 2019).

Menurut Asumsi peneliti kemampuan kepala ruangan harus sejalan dengan proses manajemen kepemimpinan yang berfokus pada asuhan keperawatan meliputi sebagai beikut:

1. Fungsi perencanaan yang tersusun mulai dari perencanaan tahunan, bulanan, mingguan dan harian, menetapkan perencanaan kebutuhan tenaga, membuat perencanaan logistic dan perencanaan pengendalian mutu.

2. Fungsi pengorganisasian kepala ruangan harus melakukan pembagian kerja sesuai kemampuan sehingga proses keperawatan dapat terlaksana, melakukan pendelegasian dan menyusun struktur organisasi untuk mengarahkan staf agar konsisten dalam tanggungjawabnya.

3. Fungsi pengarahan dimana kepala ruangan harus membantu mengidentifikasikan dan menyelesaikan masalah asuhan keperawatan pasien dan untuk meningkatkan keinginan staf untuk meningkatkan kompetensinya kepala ruangan harus melakukan pemberian reward terhadap staf yang berkompeten

4. Fungsi pengendalian merupakan proses pengukuran terhadap hasil kerja atau prestasi staf, menilai pendokumentasian asuhan keperawatan, menilai kepuasan pasien dan perawat sehingga kepala ruagan dapat mengidentifikasi masalah yang ada. 
5. Fungsi Pengawasan merupakan pengaturan kualitas pelayanan keperawatan secara dokumentasi dan kesesuaiyan dengan tindakan yang diberikan tentunya semuahal ini dapat meningkatkan kualitas pelayanan di rumah sakit.

\section{Kesimpulan}

Berdasarkan hasil penelitian maka dapat disimpulkan, Hasil kemampuan kepala ruangan rawat inap berdasarkan manajemen perencanaan sudah terencana dengan baik dan setiap minggu dan bulan meskipun ada beberapa tidak melaksanakan perencanaan tahun di RSU Datu Beru Takengon. Hasil kemampuan kepala ruangan rawat inap berdasarkan manajemen pengorganisasian tidak dilakukan dikarenakan semua perawat memiliki peran yang sama baik bidan dan perawat yang hanya melakukan metode fungsional dan untuk struktur organisasi belum terarah struktur organisasi tidak sesuai dengan tugas dan fungsinya karena masi struktur organisasi yang lama dan belum adanya penggantian strukstur yang baru di RSU Datu Beru Takengon. Hasil kemampuan kepala ruangan rawat inap berdasarkan manajemen pengarahan di RSU Datu Beru Takengon. Sudah dilaksanakan dengan baik baik meskipun terdapat beberapa kekurangan namun pengarahan untuk meningkatkan mutu pelayanan kesehatan dilaksanakan. Hasil kemampuan kepala ruangan rawat inap berdasarkan manajemen pengendalian masi kurang penatapan asuhan keperawatan dan prestasi kerja tidak ada dan dokumentasi keperawatan belum lengkap dan tidak ada menilai kepuaan perawat dan kepuasan pasien. yaitu pemberian reward di RSU Datu Beru Takengon. Hasil kemampuan kepala ruangan rawat inap berdasarkan manajemen pengawasan di RSU Datu Beru Takengon sudah baik dengan melakukan pengawasan ke ruangan dan memeriksa kebersihan ruangan. Hasil Lembar observasi dengan semua informan melaksanakan dengan baik, meski terdapat beberapa kekurangan di dokumentasi asuhan keperawatan yang belum lengkap (Sukardi, 2021).

\section{Referensi}

Astuti Yd, Dewi A, Arini M. (2017). Evaluasi Implementasi Clinical Pathway Sectio Caesarea Di Rsud Panembahan Senopati Bantul. Jmmr (Jurnal Medicoeticolegal Dan Manaj Rumah Sakit).6(2):97-111.

Barlian E. (2018). Metodologi Penelitian Kualitatif \& Kuantitatif.

Basri B, Utami T, Mulyadi E. (2020). Konsep Dasar Dokumentasi Keperawatan.

Galleryzki Ar, Hariyati Rrts, Afriani T. (2021) Hubungan Sikap Keselamatan Dengan Implementasi Sasaran Keselamatan Pasien Oleh Perawat Di Rumah Sakit. J Kepemimp Dan Manaj Keperawatan. 4(1).

Hr Hsc. (2018). Metodologi Penelitian Kesehatan Dan Pendidikan. Penebar Media Pustaka.

Ilfa Netama Khoirunnisa I, Entuy Kurniawan E, Ira Gustira Rahayu I, Sonny Feisal R S. (2020) Analisis Faktor-Faktor Yang Berhubungan Dengan Implementasi Keselamatan Pasien Di Laboratoirum. Politeknik Kesehatan Kemenkes Bandung. Moleong Lj. (2018). Metodologi Penelitian Kualitatif. Bandung: Pt. Remaja Rodakarya. Moleong Lj. (2021). Metodologi Penelitian Kualitatif. Pt Remaja Rosdakarya.

Rahmah F. (2017). Analisis Hubungan Gaya Kepemimpinan Dengan Implementasi Program Manajemen Risiko (Studi Di Rumah Sakit Islam Surabaya). Universitas Arilangga. 


\section{MIRACLE JOURNAL}

Salasa Mn. (2021). Hubungan Supervisi Kepala Ruang Dengan Penerapan Budaya Keselamatan Pasien Di Instalasi Rawat Inap Rsud Prambanan. Stikes Muhammadiyah Klaten.

Sukardi Hm. (2021) Metodologi Penelitian Pendidikan: Kompetensi Dan Praktiknya (Edisi Revisi). Bumi Aksara.

Surahmat R, Neherta M, Nurariati N. (2019). Hubungan Supervisi Dengan Implementasi Sasaran Keselamatan Pasien Di Rumah Sakit Muhammadiyah Palembang. In: Proceeding Seminar Nasional Keperawatan. 173-8.

Suwendra Iw. (2018). Metodologi Penelitian Kualitatif Dalam Ilmu Sosial, Pendidikan, Kebudayaan Dan Keagamaan. Nilacakra.

Syam Ns. (2017). Implementasi Budaya Keselamatan Pasien Oleh Perawat Di Rumah Sakit Ibnu Sina Makassar. Fak Kesehat Masy. 11(2):174-80.

Tampubolon Tr. (2019). Sikap Seorang Perawat Dalam Keselamatan Pasien Di Rumah Sakit.

Trianengsih At, Hardisman H, Almasdy D. (2019). Implementasi Permenkes Nomor 72 Tahun 2016 Tentang Standar Pelayanan Kefarmasian Di Rumah Sakit Terhadap Tatakelola Sdm Instalasi Farmasi Rsu Mayjen Ha Thalib Kerinci Tahun 2018. J Kesehat Andalas. 8(2):356-65. 